\title{
GROUP INVESTIGATION SEBAGAI PROSES PENANAMAN SIKAP TOLERANSI SISWA KELAS IX DALAM PEMBELAJARAN IPS
}

\author{
Sri Wahyuni ${ }^{1}$, Siti Maryam Yusuf ${ }^{2}$ \\ ${ }^{1}$ Institut Agama Islam Negeri Ponorogo \\ yunay5459@gmail.com \\ ${ }^{2}$ Institut Agama Islam Negeri Ponorogo \\ maryamyusuf910@yahoo.com
}

\begin{abstract}
ABSTRAK
Pendidikan di Indonesia terpengaruh perubahan global yang menuntut untuk lebih maju. Perubahan sosial budaya dan globalisasi tersebut memberikan dampak negatif dan positif terutama bagi generasi muda. Terutama terhadap degradasi moral membuat lembaga pendidikan dan seluruh elemen pendorongnya untuk lebih menekankan akan pentingnya pengetahuan dan penerapan sikap toleransi dalam kehidupan sehari-hari dalam meminimalisir perilaku-perilaku menyimpang yang dapat dilakukan oleh siswa. Oleh sebab itu diperlukannya strategi pembelajaran yang dapat menumbuhkan sikap toleransi siswa sejak dini. Penelitian ini bertujuan untuk mengetahui penerapan group investigation dalam menanamkan sikap toleransi siswa kelas IX dalam pembelajaran IPS di SMPN 1 Mlarak, dengan rancangan metode penelitian kualitatif dengan metode dokumentasi, observasi, dan wawancara. Berdasarakan hasil analisis data ditemukan bahwa (1) penerapan model pembelajaran group investigation meliputi: pemilihan topik materi, yang terorganisir pada Bab Perubahan Sosial Budaya dan Globalisasi, perencanaan kooperatif, implementasi, analisis dan sintesis, pengumpulan hasil akhir, evaluasi. (2) adapun faktor penghambat dan pendorongnya berasal dari sikap bawaan, keluarga, pergaulan, dan masyarakat (3) Adapun hasil dari penanaman sikap toleransi siswa melalui model pembelajaran group investigation yaitu sikap toleransi beragama, sikap saling membantu dan bekerja sama dalam menyelesaikan tugas, sikap kepedulian terhadap sesama, dan sikap toleransi dengan tidak membeda-bedakan siswa lain dalam hal fisik dan akademik.

Kata Kunci: Group investigation, Sikap Toleransi, IPS.
\end{abstract}

\section{ABSTRACT}

Education in Indonesia is affected by global changes that demand to be more advanced. These socio-cultural changes and globalization have had negative and positive impacts, especially for the younger generation. Especially for moral degradation, educational institutions and all driving elements emphasize the importance of knowledge and the application of tolerance in everyday life in minimizing deviant behaviors that can be done by students. Therefore, it is necessary to have a learning strategy that can foster tolerance for students from an early age. This study aims to determine the application of group investigation in instilling tolerance for grade IX students in social studies learning at SMPN 1 Mlarak, with a qualitative research method design using documentation, observation, and interview methods. Based on the results of data analysis, it was found that (1) the application of the group investigation learning model included: selection of material topics, which were organized in the Chapter of Socio-Cultural Change and Globalization, cooperative planning, implementation, analysis and synthesis, collection of final results, evaluation. . (2) the inhibiting and driving factors come from innate attitudes, family, association, and society (3) The results of the cultivation of students' tolerant attitudes through the group investigation learning model are attitudes of religious tolerance, mutual help and cooperation incompleting assignments, an attitude 


\section{Group Investigation Sebagai Proses Penanaman Sikap Toleransi Siswa Kelas IX dalam Pembelajaran IPS}

of caring for others, and an attitude of tolerance without discriminating against other students in physical and academic terms.

Keywords: Group investigation, Tolerance Attitude, IPS.

\section{PENDAHULUAN}

Perkembangan dan perubahan dibidang sosial, ekonomi, budaya, politik, dan pendidikan di Indonesia tidak terlepas dari pengaruh perubahan global yang semakin menuntut untuk lebih maju. Hal utamanya adalah pada bidang pendidikan. Perubahan secara terus menerus ini menuntut perlunya perbaikan sistem pendidikan nasional dan memunculkan persaingan dalam berbagai bidang kehidupan terutama dalam bidang lapangan pekerjaan yang menjadi tujuan di masa depan. Kemerosotan moral bangsa dengan adanya berbagai macam perpecahan, konflik, dan perbedaan dianggap sebuah kesalahan oleh oknum radikal yang telah menyeret Indonesia kedalam masalah toleransi yang cukup serius. Fenomena-fenomena di atas merupakan bukti nyata dari pernyataan Thomas Lickona (Akhmad Sudrajat, 2011), yang menyatakan bahwa ada 10 aspek degradasi moral yang melanda suatu negara yang merupakan tandatanda kehancuran suatu bangsa. Tada- tanda tersebut adalah:

1. Meningkatnya kekerasan pada remaja

2. Penggunaan kata-kata yang memburuk

3. Pengaruh peer group (rekan kelompok) yang kuat dalam tindak kekerasan

4. Meningkatnya penggunaan narkoba, alkohol, dan seks bebas

5. Kaburnya batasan moral baik-buruk

6. Menurunnya etos kerja

7. Rendahnya rasa hormat kepada orang tua dan guru

8. Rendahnya rasa tanggung jawab individu dan warga negara

9. Membudayanya ketidakjujuran

10. Adanya saling curiga dan kebencian di antara sesama.

Diketahui SMPN 1 Mlarak merupakan satu-satunya sekolah menengah negeri dan favorit yang ada di wilayah Kecamatan Mlarak. Sekolah yang berada di wilayah semi perkotaan ini, memiliki siswa yang beraneka ragam budaya, adat, dan agama. Dari hasil observasi pertama yang dilakukan peneliti, ditemui salahsatu konflik antarsiswa yang terjadi di SMPN 1 Mlarak, yaitu ejekan terhadap teman yang lain. Ejekan yang terjadi di area sekolah ini memang tidak memiliki efek besar terhadap kegiatan belajar, namun tetap menjadi perhatian guru dalam penyelesaiannya.

Masalah tersebut biasanya berawal dari saling ejek antarteman karena nama atau fisik besar kecil, yang kemudian muncul sikap saling tidak terima. Lembaga pendidikan yang berkewajiban memberikan rasa nyaman dan aman, sudah seyogyanya memberikan bimbingan terhadap siswa agar berperilaku baik terhadap sesama dan lingkungannya. Sehingga dari hal tersebut, sikap toleransi harus ditanamkan kepada setiap jiwa siswa. Terbentuknya sikap toleransi harus didasari sikap lapang dada kepada orang lain dengan memperhatikan prinsipprinsip yang dipegang sendiri. Toleransi akan terjadi dan berlaku karena adanya 
perbedaan prinsip dan menghormati perbedaan atau berprinsip orang lain tanpa mengorbankan prinsip sendiri. Sehingga dengan adanya bimbingan dari guru dalam pendidikan diharapkan mampu memberikan sumbangsih besar terhadap hal ini.

Tujuan belajar yang pada umumnya adalah untuk mencapai perubahan dalam tingkah laku yang dimaksudkan untuk hal-hal bersifat positif untuk membantu proses perkembangan. Dengan menemukan metode dan pendekatan serta model yang dipilih dalam pembelajaran yang tepat maka akan membawa pengaruh yang baik terhadap pola pengajaran maupun hasil akhir yang dicapai. Selain itu, metode yang digunakan juga dimaksudkan selain pengetahuan yang didapat juga pengembangan sikap baik pada siswa. Salah satunya yang dapat digunakan dalam mata pelajaran IPS yaitu dengan pembelajaran kooperatif tipe group investigation. Group investigation adalah metode belajar secara kelompok yang dilakukan oleh siswa. Model pembelajaran group investigation ini membantu guru mengaitkan antara materi yang diajarkan dengan situasi dunia nyata siswa dan mendorong siswa untuk membuat hubungan antara materi yang yang diajarkan dengan situasi dunia nyata melalui pengetahuan yang dimiliki dengan penerapannya dalam kehidupan sehari-hari dalam bersosial masyarakat. Sehingga melalui model tersebut diharapkan berguna positif untuk perkembangan sikap toleransi siswa pada diri siswa, keluarganya, serta lingkungan yang ada di sekitarnya.

\section{METODE PENELITIAN}

Pada penelitian ini, digunakan pendekatan penelitian kualitatif. Pendekatan kualitatif adalah prosedur penelitian yang menghasilkan data deskriptif berupa kata-kata tertulis atau lisan dari orang-orang dan perilaku yang dapat diamati. ${ }^{1}$ Serta jenis penelitian yang digunakan dalam penelitian ini adalah studi kasus dengan pengumpulan data melalui wawancara, observasi, dan dokumentasi. Maka dari itu kehadiran peneliti adalah mutlak karena peneliti harus berinteraksi dengan lingkungan penelitian yang berlokasi di SMPN 1 Mlarak. Berdasarka kesesuaian kondisi, situasi, lingkungan, serta topik yang diteliti oleh peneliti.

Adapun data dalam penelitian ini adalah 1) data terkait sejarah, visi, misi, tujuan, sarana prasarana, struktur organisasi, kondisi guru, tenaga kependidikan, siswa, serta ekstrakurikuler didapat melalui teknik dokumentasi, 2) data terkait penerapan, faktor penghambat dan pendukung, serta hasil dari group investigation dalam menanamkan sikap toleransi didapat dari teknik wawancara dengan Ibu Titis selaku guru IPS kelas IX, Ibu Endang selaku wali kelas IX, serta siswa kelas IX dan juga proses observasi terhadap pembelajaran guru dan tindakan siswa. Data yang dikumpulkan kemudian dianalisis menggunakan konsep miles dan huberman yang mengemukakan tiga tahapan yaitu reduksi data, penyajian data

${ }^{1}$ Moleong Lexy, Metodologi Penelitian Kualitatif (Bandung: PT Remaja Rosda Karya, 2009), 3. 


\section{Group Investigation Sebagai Proses Penanaman Sikap Toleransi Siswa Kelas IX dalam Pembelajaran IPS}

dan penarikan kesimpulan. Keabsahan data merupakan konsep penting yang diperbaruhi dari konsep validitas dan reabilitas. ${ }^{2}$

Berikut beberapa teknik pengecekan keabsahan data dalam proses penelitian diantaranya adalah perpanjang keikutsertaan, pengamatan yang tekun, dan triangulasi. $^{3}$ 1) Perpanjangan keikutsertaan. Peneliti dalam penelitian kualitatif adalah instrumen itu sendiri. Keikutsertaan peneliti sangat menentukan dalam pengumpulan data. Dalam hal ini keikut sertaan tersebut tidak hanya dilakukan dalam waktu singkat, tetapi memerlukan perpanjangan keikut sertaan peneliti pada latar penelitian, 2) Ketekunan pengamatan. Ketekunan pengamatan bermaksud menemukan ciri-ciri dan unsur-unsur dalam situasi yang sangat dicari dan kemudian memusatkan dari pada hal-hal tersebut secara rinci. Ketekunan pengamatan ini dilakukan peneliti dengan cara mengadakan pengamatan dengan teliti dan rinci secara berkesinambungan terkait dengan penanaman sikap toleransi siswa kelas IX melalui model group investigation dalam pembelajaran IPS di SMPN 1 Mlarak, 3) Triangulasi. Triangulasi dalam pengujian kredibilitas ini diartikan sebagai pengecekan data dari berbagai sumber dengan berbagai cara dan berbagai waktu. Adapun proses triangulasi dalam penelitian ini dilakukan pada triangulasi sumber dan triangluasi teknik.

Tahapan-tahapan penulisan dalam penelitian ini ada tiga tahapan dan ditambah dengan tahap terakhir dari penelitian yaitu tahap penulisan laporan hasil penelitian. Tahap-tahap penelitian tersebut adalah: 1) Tahap pra lapangan, ada enam yang meliputi, menyusun rancangan penelitian, memilih lapangan lokasi penelitian, mengurus perizinan, menjajaki dan menilai keadaan lapangan, memilih dan memanfaatkan informan, menyiapkan perlengkapan penelitian dan persoalan etika penelitian, 2) Tahap pekerjaan lapangan, yang meliputi uraian tentang tahap pekerjaan lapangan dibagi atas tiga bagian yaitu: memahami latar penelitian dan persiapan diri, memasuki lapangan, dan berperan serta sambil mengumpulkan data, 3) Tahap analisis data, yang meliputi: analisis data selama pengumpulan data dan setelah pengumpulan data, 4) Tahap penulisan hasil laporan. ${ }^{4}$

\section{HASIL DAN PEMBAHASAN}

Hasil penelitian yang penulis dapatkan tentang pembelajaran IPS di SMPN 1 Mlarak menunjukkan bahwasannya keefektifan pembelajaran dapat diraih, jika siswa mendapatkan kondisi belajar yang tidak menekankan pada banyaknya tugas individual yang harus dikerjakan. Hal ini berkaitan erat dengan situasi pembelajaran yang bersifat dalam jaringan atau daring sejak mewabahnya virus covid-19. Kecerdesaan intelektual tidak hanya menjadi faktor utama keberhasilan pembelajaran IPS yang dilakukan. Namun, karakter siswa juga merupakan wujud

${ }^{2}$ Michael B, Mattew; A, Miles; Huberman, Analisis Data Kualitaif (Jakarta: UI Press, 1992), 16.

${ }^{3}$ Lexy, Metodologi Penelitian Kualitatif, 175.

${ }^{4}$ Basrowi; Suwandi, Memahami Penelitian Kualitatif (Jakarta: Rineka Cipta, 2008), 8491. 
salah satu penentu keberhasilan belajar siswa. Salah satu karakter yang harus ditanamkan dalam diri siswa saat ini adalah karakter/ sifat toleransi.

Sebagaimana yang digenjarkan oleh Kementerian Pendidikan dan Budaya Indonesia, Bapak Nadhiem Anwar Makarim. Beliau menuturkan bahwa, "Pendidikan di Indonesia harus berjalan dengan adanya toleransi tinggi". 5 Hal ini beliau genjarkan sebagai bentuk penyikapan terhadap adanya bullying, intimidasi ras, suku, dan agama serta lain sebagainya yang terjadi di lingkungan pendidikan Indonesia. Penerapan sikap toleransi pada siswa bukanlah hal yang mudah untuk dilakukan, selain memerlukan model pembelajaran yang tepat juga membutuhkan waktu yang lama.

Pentingnya bagi seorang siswa tertanam nilai sikap toleransi adalah agar siswa dapat saling memahami antarteman dan mampu bekerjasama dalam kegiatan belajar sehingga dapat mencapai hasil belajar yang maksimal. Hal tersebut juga berfungsi untuk mengembangkan pribadi siswa menjadi pribadi yang baik bagi dirinya sendiri, keluarga, dan lingkungannya. Adapun salah satu cara dalam menanamkan sikap toleransi pada pembelajaran IPS di sekolah adalah dengan penerapan model pembelajaran group investigation, sebagaimana pembahasan dalam penelitian ini yakni sebagai berikut:

\section{Proses Penerapan Group Investigation Dalam Penanaman Sikap Toleransi Siswa Kelas IX Dalam Pembelajaran IPS di SMPN 1 Mlarak}

Pembelajaran dapat dikatakan sebagai suatu hasil dari memori, kognisi, dan metakognisi yang berpengaruh terhadap pemahaman tiap-tiap individu. Pembelajaran pada hakikatnya tidak selalu mengarah pada lembaga pendidikan. Namun dapat terjadi dimanapun, kapanpun, dan pada strata apapun, baik secara individual, kolektif, ataupun sosial yang berorientasi pada tujuan di masa depan. Model pembelajaran group investigation yang bersifat membentuk kelompokkelompok kecil ini berasal dari premis bahwa dalam bidang sosial maupun intelektual, proses pembelajaran tetap menggabungkan nilai-nilai budi pekerti luhur. $^{6}$

Miftahul Huda dalam bukunya, ia menerangkan bahwa tampak dua definisi pembelajaran dari berbagai perspektif teoritis terkait praktik pembelajaran. Pertama, pembelajaran bersifat sebagai sebuah perubahan perilaku. Salah satu contohnya ialah ketika seseorang belajar bersikap acuh dalam kelas ternyata dapat berubah menjadi seseorang yang sangat perhatian. Kedua, pembelajaran sebagai perubahan kapasitas. Seperti contohnya ketika seseorang takut pada pelajaran tertentu ternyata ia dapat berubah menjadi sangat percaya diri dalam menyelesaikan pekerjaan tersebut. ${ }^{7}$ Berikut merupakan langkah-langkah

${ }^{5}$ https://itjen.kemendikbud.go.id/public/post/detail/contoh-baik-toleransi, diakses pada 29 April 2021, 14:20 WIB.

${ }^{6}$ Isjoni, Cooperative Learning Efektivitas Pembelajaran Kelompok,, 87.

${ }^{7}$ Miftahul Huda, Model-model Pengajaran dan Pembelajaran, (Yogyakarta: Pustaka Pelajar, 2013), 5. 


\section{Group Investigation Sebagai Proses Penanaman Sikap Toleransi Siswa Kelas IX dalam Pembelajaran IPS}

yang digunakan oleh guru IPS SMPN 1 Mlarak sebagai acuan model pembelajaran group investigation dalam pembelajaran IPS :

1. Pemilihan topik. Pemilihan topik ini berguna untuk menentukan subtopik yang akan didiskusikan oleh siswa. ${ }^{8}$ Dalam hal ini guru mengorientasikan terlebih dahulu terkait tema besar atau masalah umum yang akan dibahas. Kemudian mereka diorganisasikan kedalam kelompok-kelompok yang berorientasi pada tugas yang beranggotakan 3-4 siswa, yang bersifat heterogen baik dari jenis kelamin, suku, agama, maupun kemampuan akademik. $^{9}$

2. Perencanaan kooperatif. Pada langkah ini siswa dan guru merencanakan berbagai prosedur belajar khusus, tugas, dan tujuan umum yang konsisten terhadap berbagai subtopik yang telah dipilih pada langkah pertama. ${ }^{10}$

3. Implementasi. Implementasi ini dilakukan oleh siswa dengan bimbingan dari guru. Biasanya pada langkah ini guru akan memberikan kebebasan kepada siswa untuk bereksplorasi terhadap berbagai sumber belajar, baik di dalam atau di luar sekolah. Tugas guru saat langkah ini dilakukan adalah sebagai pemerhati mengikuti kemajuan tiap-tiap kelompok serta membantu kelompok jika mengalami kesulitan.

4. Analisis dan sintesis. Tahap ini, menuntut siswa untuk menganalisis dan membuat sintesis dari berbagai informasi yang diperoleh pada langkah sebelumnya, dan mencoba menyimpulkan menjadi tugas hasil akhir dalam kelompok, yang kemudian disajikan menarik sabagai presentasi di depan kelas. $^{11}$

5. Presentasi hasil final. Semua kelompok yang dikoordinir oleh guru membagikan hasil dari subtopik yang mereka bahas dalam kelompok untuk seluruh anggota kelas, sehingga siswa lain juga mendapatkan pengetahuan dari kelompok lainnya. ${ }^{12} \mathrm{Hal}$ ini terhalang secara tatapmuka akibat pandemi covid-19.

6. Evaluasi ${ }^{13}$. Tahap evaluasi ini guru bersama-sama dengan siswa melakukan evaluasi terhadap konstribusi tiap kelompok pada tugas yang diberikan oleh guru. Evaluasi ini dapat dilakukan baik secara individual atau kelompok ataupun keduanya, dengan dapat menambahkan khazanah pengetahuan moral bagi siswa tentang sikap sosial. ${ }^{14}$ Hal tersebut selaras dengan yang dilakukan oleh Ibu Titis selaku evaluator terhadap hasil kinerja dan sikap siswa terkait materi Perubahan Sosial Budaya dan Globalisasi.

\footnotetext{
${ }^{8}$ Miftahul Huda, Model-model Pengajaran dan Pembelajaran, 293.

${ }^{9}$ Agus Suprijono, Cooperative Learning, (Yogyakarta: Pustaka Pelajar, 2009),112.

${ }^{10}$ Agus Suprijono, Cooperative Learning, 112.

${ }^{11}$ Miftahul Huda, Model-model Pengajaran dan Pembelajaran, 294.

${ }^{12}$ Rusman, Model-model Pembelajaran, 222.

${ }^{13}$ Miftahul Huda, Cooperative Learning, (Yogyakarta: Pustaka Pelajar, 2011), 123.

${ }^{14}$ Aunurrahman, Belajar dan Pembelajaran, 152.
} 
SMPN 1 Mlarak telah melaksanakan penerapan model pembelajaran group investigation dalam menumbuhkan sikap toleransi siswa kelas IX tersebut sejak awal pertemuan pada tahun ajaran 2020/2021. Langkah-langkah yang menyesuaikan siswa diera pandemi telah Ibu Titis optimalkan secara keseluruhan dengan cara yang mudah dan sederhana. Sehingga penerapan model pembelajaran group investigation telah dilaksanakan secara konsisten dan semaksimal mungkin.

\section{Faktor Pendukung Dan Penghambat Penerapan Group Investigation Dalam Penanaman Sikap Toleransi Siswa Kelas IX Dalam Pembelajaran IPS di SMPN 1 Mlarak}

Berhubungan dengan model pembelajaran yang digunakan guru sebagai model pembelajaran dalam mengajar, tentunya terdapat hambatan dan dorongan. Pembelajaran daring merupakan pembelajaran yang menggunakan jaringan internet dengan aksesibilitas, konektivitas, fleksibilitas, dan kemampuan untuk memunculkan berbagai jenis interaksi dalam pembelajaran. ${ }^{15}$ Diuraikan dalam Jurnal Ilmiah Pendidikan Biologi, tantangan pembelajaran daring secara umum adalah berasal dari lingkungan diri siswa. ${ }^{16}$

Faktor lingkungan masyarakat menjadi sorotan pembelajaran daring yang kini diterapkan. Pendidikan yang berfungsi sebagai pembentuk nilai, norma semakin sulit untuk ditumbuhkan. Hal ini disebabkan minimnya kontrol guru terhadap siswanya karena pembelajaran daring yang dilakukan di rumah masingmasing. Adapun faktor penghambat dan pendorong penanaman sikap toleransi siswa melalui model pembelajaran group investigation dalam pelajaran IPS terdiri dari :

1. Diri siswa yang berupa tabiat yang dimiliki dan semnagatnya. Hal ini jelas berpengaruh terhadap mudah atau sulitnya penanaman sikap toleransi dalam diri siswa. Karena saat siswa itu sendiri tidak mau berubah maka akan sangat sulit guru atau yang lainnya untuk mampu menumbuhkan sikap toleransinya.

2. Lingkungan keluarga. Hal ini terkait dengan pola asuh orang tua atau yang mendidiknya di rumah. Dari hasil observasi lapangan diketahui bahwa sebagian besar siswa kelas IX di SMPN 1 Mlarak tinggal bersama nenek, kakek, bapak, atau ibu cerai. Sehingga dapat dilihat perhatian terhadap anak juga kurang.

3. Pergaulan. Teman sebaya juga memiliki pengaruh besar dalam penanaman sikap toleransi siswa. Hal tersebut berkaitan erat bahwa anak yang masih pada masa pubertas biasanya masih akan selalu ikut-ikutan terhadap sesamanya. Sehingga baik buruknya akan dapat dilihat dari teman sebayanya.

\footnotetext{
${ }^{15}$ Ali Shadiqin dan Afreni Hamidah, Pembelajaran Daring di Tengah Wabah Covid-19, Ilmiah Pendidikan Biologi Vol 6 No. 2 (2020), 216.

${ }^{16}$ Ali Shadiqin dan Afreni Hamidah, Pembelajaran Daring di Tengah Wabah Covid-19, 218.
} 


\section{Group Investigation Sebagai Proses Penanaman Sikap Toleransi Siswa Kelas IX dalam Pembelajaran IPS}

4. Masyarakat. Lingkungan sekitar juga memiliki pengaruh terhadap sikap siswa, karena sejatinya sikap masyarakatlah yang dapat membentuk ragam karakter siswa dalam lingkungannya. ${ }^{17}$

Sehingga hal tersebut menjadi sebuah tantang bagi guru untuk aktif, tanggap, dan kreatif dalam menyelesaikan masalah-masalah yang dihapai siswa. Sehingga penilaian terhadap aspek afektif siswa hanya dapat terbatas dari observasi guru, siswa sebagai temannya, dan angket yang diberikan.

\section{Hasil Penerapan Group Investigation Dalam Penanaman Sikap Toleransi Siswa Kelas IX Dalam Pembelajaran IPS di SMPN 1 Mlarak}

Toleransi merupakan sikap saling menghormati dan menghargai antarindividu dengan individu lainnya atau antarindividu dengan kelompok atau antar kelompok dengan kelompok dalam lingkungan sosial. Indonesia yang merupakan negara multikultural, sudah seharusnya menanamkan sikap toleransi terhadap setiap warga negaranya. Sikap toleransi ini berarti sifat menghormati dan menghargai terhadap perbedaan guna menjaga kesatuan dan persatuan.

Pendidikan karakter sebaiknya memang dikembangkan melalui pendekatan yang komprehensif, dengan menggunakan semua aspek persekolahan sebagai peluang untuk pengembangan karakter. ${ }^{18}$ Seperti yang dijelaskan oleh Kementerian Pendidikan, bahwa terdapat tiga cara dalam menumbuhkan sikap toleransi siswa dalam pendidikan yaitu :

1. Program pengembangan diri, yang meliputi kegiatan rutin, kegiatan spontan, keteladanan, dan pengkondisian.

2. Pengintegrasian dalam mata pelajaran, yang meliputi strategi guru dalam mengajar dan model pelajaran yang digunakan oleh guru dan siswa.

3. Budaya sekolah, yang berkenaan dengan norma dan nilai yang diterapkan di lingkungan sekolah. ${ }^{19}$

Dari hal tersebut jelas bahwa sifat toleransi memang seharusnya menjadi karakter dasar yang harus dimiliki oleh seseorang. Seperti yang dijelaskan oleh Sri Soryani, bahwa indikator sikap toleransi ada dua yaitu :

1. Saling menghormati antarsesama tanpa memandang suku, agama, ras, atau aliran.

2. Saling membantu antarsesama dalam kebaikan. ${ }^{20}$

Sedangkan sikap toleransi yang harus ada dalam diri siswa pada mata pelajaran IPS adalah sebagai berikut:

\footnotetext{
${ }^{17}$ Yuni Maya Sari, Pembinaan Toleransi dan Peduli Sosial dalam Upaya Memantapkan Watak Kewarganegaraan (Civic Disposition) Siswa, Pendidikan Ilmu Sosial Vol 23 No. 1, (Juni 2014), 32.

${ }^{18}$ Zubaedi, Desain Pendidikan Karakter: Konsepsi dan Aplikasinya Dalam Lembaga Pendidikan, (Jakarta: Kencana, 2011), 117.

${ }^{19}$ Astri Dayanti, Skripsi: "Pengembangan Sikap Toleransi Terhadap Perbedaan Pendapat Siswa Melalui Discovery Learning dalam Pembelajaran IPS”. 36

${ }^{20}$ Sri Soryani, Penanaman sikap toleransi di kelas V SD Negeri Styono III Kecamatan Playen Kabupaten Gunung Kidul, Yogyakarta: Universitas Negeri Yogyakarta (Juli 2015), 33-34.
} 
1. Bersikap dan menghormati guru, siswa lain, dan anggota sekolah sebagai wujud menghormati dan menghargai antarsesama

2. Toleransi terhadap perbedaan agama dalam anggota sekolah

3. Toleransi terhadap perbedaan ras, suku bangsa, dan adat istiadat dalam anggota sekolah yang berdasar pada multikultural NKRI

4. Toleransi terhadap perbedaan fisik sesama siswa

5. Toleransi terhadap perbedaan kemampuan intelektual antarsiswa

6. Menghargai pendapat siswa lain dalam pembelajaran atau musyawarah kelas.

7. Toleransi terhadap situasi dan kondisi siswa lain, karena hal tersebut berkenaan dengan sikap toleransi dalam kehidupan sosial. ${ }^{21}$

Dari sikap-sikap toleransi diatas maka dapat disimpulkan bahwa sikap toleransi yang harus ada dalam diri siswa meliputi :

1. Sikap toleransi beragama

2. Sikap toleransi bersosial

Hasil dari penelitian, SMPN 1 Mlarak telah berhasil melakukan praktek tersebut untuk menanamkan sikap toleransi melalui pembelajaran IPS dengan metode group investigation. Data tersebut diperoleh dari perubahan siswa dalam aspek toleransi dan dari hasil pembiasan model pembelajaran yang telah diterapkan. Berikut beberapa sikap toleransi yang dimiliki siswa kelas IX di SMPN 1 Mlarak :

1. Sikap toleransi beragama yang tercermin dari sikap siswa yang saling menghormati dan menghargai perbedaan agama dalam lingkungan SMPN 1 Mlarak. Hal ini diketahui dari hasil observasi, bahwa terdapat pula guru IPS non islam di lingkungan SMPN 1 Mlarak.

2. Sikap toleransi bersosial yang tercermin dalam kelompok yang saling membantu dan bekerja sama dalam menyelesaikan tugas serta sikap toleransi dengan wujud kepedulian terhadap sesama siswa dan sikap toleransi dengan tidak membeda-bedakan siswa lain dalam hal fisik dan akademik.

\section{KESIMPULAN}

Berdasarkan dari penelitian kualitatif yang digunakan peneliti untuk menelusuri seluruh informasi terkait dengan model pembelajaran group investigation pada mata pelajaran IPS kelas IX di SMPN 1 Mlarak yang bertujuan untuk menumbuhkan sikap toleransi pada setiap siswanya, maka diperolehlah hasil sebagai berikut : 1) Penerapan model pembelajaran group investigation dalam pembelajaran IPS secara daring yang diterapkan di SMPN 1 Mlarak mengacu pada acuan model langkah pembelajaran group investigation sebagai berikut, yang meliputi: pemilihan topik materi, perencanaan kooperatif, implementasi, analisis dan sintesis, pengumpulan kesimpulan hasil akhir, dan

${ }^{21}$ Astri Dayanti, Skripsi: "Pengembangan Sikap Toleransi Terhadap Perbedaan Pendapat Siswa Melalui Discovery Learning dalam Pembelajaran IPS". 


\section{Group Investigation Sebagai Proses Penanaman Sikap Toleransi Siswa Kelas IX dalam Pembelajaran IPS}

evaluasi. 2) Adapun faktor penghambat dan pendorong dalam model pembelajaran group investigation dalam penanaman sikap toleransi siswa kelas IX di SMPN 1 Mlarak yang berupa internalisasi dari diri siswa baik atau kurang baiknya yang menjadi kebiasaan dan juga terpengaruh banyak dari lingkungan kehidupan siswa mulai dari pola asuh dalam keluarga, pergaulan, serta lingkungan masyarakat sekitarnya. 3) Hasil dari penanaman sikap toleransi siswa melalui model pembelajaran group investigation dalam pembelajaran IPS di SMPN 1 Mlarak tercermin dalam sikap toleransi dalam beragama di lingkungan sekolah serta sikap toleransi siswa dalam kehidupan sosial yang berupa sikap kepedulian terhadap sesama, saling bekerjasama dalam mencapai tujuan, serta toleransi dalam hal fisik dan akademik.

\section{DAFTAR PUSTAKA}

Aunurrahman, Belajar dan Pembelajaran, Bandung: Alfabeta, 2010.

Basrowi dan Suwandi, Memahami Penelitian Kualitatif, Jakarta: Rineka Cipta, 2008.

Dayanti, Astri, Skripsi: Pengembangan Sikap Toleransi Terhadap Perbedaan Pendapat Siswa Melalui Discovery Learning dalam Pembelajaran IPS, Bandung: UPI.

Huda, Miftahul, Cooperative Learning, Yogyakarta: Pustaka Pelajar, 2011.

Huda, Miftahul, Model-model Pengajaran dan Pembelajaran, Yogyakarta: Pustaka Pelajar, 2013.

Isjoni, Cooveratif Learning Efektivitas Pembelajaran Kelompok, Bandung: Alfabeta, 2009.

Michael B, Mattew; A, Miles Huberman, Analisis Data Kualitaif Jakarta: UI Press, 1992.

Moloeng, Lexy J., Metedologi Penelitian Kualitatif, Bandung: Remaja Rosda Karya, 2009.

Sari, Yuni Maya, Pembinaan Toleransi dan Peduli Sosial dalam Upaya Memantapkan Watak Kewarganegaraan (Civic Disposition) Siswa, Pendidikan Ilmu Sosial Vol 23 No. 1, Juni 2014.

Shadiqin, Ali dan Afreni Hamidah, Pembelajaran Daring di Tengah Wabah Covid-19, Ilmiah Pendidikan Biologi Vol 6 No. 2, 2020.

Soryani, Sri, Penanaman sikap toleransi di kelas V SD Negeri Styono III Kecamatan Playen Kabupaten Gunung Kidul, Yogyakarta: Universitas Negeri Yogyakarta, Juli 2015.

Suprijono, Agus, Cooperative Learning, Yogyakarta: Pustaka Pelajar, 2009.

Zubaedi, Desain Pendidikan Karakter: Konsepsi dan Aplikasinya Dalam Lembaga Pendidikan, Jakarta: Kencana, 2011.

https://itjen.kemendikbud.go.id/public/post/detail/contoh-baik-toleransi, diakses pada 29 April 2021, 14:20 WIB. 